\title{
The Meaning in English Airplane Company Slogans : Semantic Studies.
}

Patria Supriyoso, Ria Nirwana and R. Yeni Dewi Cahyani

\author{
English Department, Faculty of Letters, Al-Ghifary University, Jl. A.H. \\ Nasution-Sukamiskin no.247, Bandung, 4093, Indonesia \\ patriapriyoso@gmail.com
}

\begin{abstract}
ABSTRACK
The aims of this study were to find out the types of meaning, and advertising objectives in airplane company slogans. Based on the research phenomenon, public does not understand the meaning of the message of the English slogan of the airline company as an advertising medium for the public. This research was conducted by using descriptive qualitative design. The data consisted of 42 airplane company which operated in Indonesia. The data were analysed by using the seven types of meaning theory by G. Leech (1981) and advertising objective theory by (Kotler, PhilipEKeller, Kevin Lane: 2009). The data were divided into Seven Types of meaning, they were Conceptual meaning, Connotative meaning, Social meaning, Affective meaning, Reflected meaning, Collocative meaning, and Thematic meaning. The data were also analysed by using advertising objective, they were to inform, to persuade, and to remind. The final results of analyzing the activities of 42 English slogans of airplane company slogans operating in Indonesia were found using Thematic meaning.The main theme that is usually carried is usually always related to safety, so it's not surprising that there are many words of "safety" that are the focus and emphasis in their slogans. Some other airplane company try to say in their slogan that the company is better, more friendly, warmer in terms of comfort in traveling using their airplane company.The final result of the analysis of 42 English slogans of airplane company operating in Indonesia that the researcher found that the company's goal of advertising slogans were to inform customers.
\end{abstract}

Keywords: Semantics, Types of Meaning, Airplane Company, Slogans.

\begin{abstract}
ABSTRAK
Tujuan dari penelitian ini adalah untuk mengetahui jenis makna, dan tujuan periklanan dalam slogan perusahaan penerbangan. Berdasarkan fenomena penelitian, publik tidak memahami makna pesan dari slogan berbahasa Inggris perusahaan penerbangan sebagai media iklan untuk publik. Penelitian ini dilakukan dengan menggunakan desain deskriptif kualitatif. Data terdiri dari 42 perusahaan penerbangan yang beroperasi di Indonesia. Data dianalisis dengan menggunakan tujuh jenis teori makna oleh G. Leech (1981) dan teori tujuan periklanan oleh (Kotler, Philip \& Keller, Kevin Lane: 2009). Data dibagi menjadi tujuh jenis makna, yaitu makna konseptual, makna konotatif, makna sosial, makna afektif, makna refleksi, makna kolokatif, dan makna tematik. Data juga dianalisis dengan menggunakan tujuan periklanan, to inform, to persuade, dan to remind. Hasil analisa akhir dari 42 slogan bebahashasa Inggris dari slogan perusahaan penerbangan yang beroperasi di Indonesia ditemukan menggunakan makna Tematik. Tema utama yang biasanya diangkat selalu berkaitan dengan keselamatan,
\end{abstract}


sehingga tidak mengherankan bahwa ada banyak kata "safety". Hal tersebut merupakan fokus dan penekanan dalam slogan perusahan-perusahaan tersebut. Beberapa perusahaan penerbangan lain mencoba mengatakan dalam slogan mereka bahwa perusahaan penerbangan mereka lebih baik, lebih ramah, lebih hangat dalam hal kenyamanan dalam perjalanan menggunakan perusahaan penerbangan mereka. Hasil analisis dari 42 slogan berbahasa Inggris dari perusahaan penerbangan yang beroperasi di Indonesia bahwa peneliti menemukan bahwa tujuan perusahaan dari slogan tersebut adalah untuk memberi tahu pelanggan.

\section{Kata kunci: Semantik, Jenis Makna, Perusahaan Penerbangan, Slogan}

\section{INTRODUCTION}

Language plays a key role in all aspects of human life as it means of communication. Language is used to provide information, ask others to do certain things, as means to express feelings, moods, ideas and experiences to others. Sapir (1921: 7) states that language is a purely human and noninstinctive method of communicating ideas, emotions, and desires to use voluntarily produced symbol systems.

Today, it is widely believed that English is an international language or a global language. There is no official definition of "international" or "global" language, but basically refers to internationally learned and spoken language. It is not only characterized by the number of native speakers and their second language, but also by its geographical location, distribution, and use in international organizations and in diplomatic relations. (Mastin: 2011)

English as an international language acts as a "lingua franca", a common language that allows people of different
According to the World Economic Forum report at Davos 2019, the world's population currently reaches 7.7 million. English is the official language of several major countries, and based on data it is estimated that the number of people in the world who use English as a medium to communicate about 1.5 billion people. According to data reported by w3techs.com in 2018, English is the most widely used language on the internet that is equal to $51.6 \%$, followed by Russian 6.6\%, Japan 5.6\%, Spain 5.1\%.

backgrounds and ethnicities to communicate on a more or less equal basis. Therefore, English in the center of such an international activity by itself will have a global status. (Crystal David, 2003: 10)

Considerations as International language, English proved widely used by a number of international and domestic airplane company operating in Indonesia to conduct marketing activities. Advertising and sales promotion activities choose to use English slogansusing offline media (brochure, pamphlet, newspaper, 
magazine, banner, $\mathrm{TV}$, radio) slogans are usually rarely installed on the fuselage and also use media online via internet websites to communicate messages, convince, and also remind customers of their products / services. English slogan can be regarded as a series of short words in English that are generally interesting and memorable, serves to influence the audience as desired slogan maker.

The meanings contained in the writings of English slogans are closely related to semantics. Chaer(1990: 6) said that the object of semantic study is the meaning of language. Again, the meaning of language units such as words, phrases, clauses, sentences, and discourses. Stephen Ulman (2014: 65) stated that meaning is the most ambiguous and most controversial term in the language.

In this study the researcher will be focused and completed on a number of English slogans of airplane companies operating in Indonesia using theory of meaning (Leech, 1981: 23) there are 7 types of meanings. Before carrying out the actual research, the researcher conducted a preliminary study intensif which was to get a job that made it possible to be clear and focus in its position (Sugiyono, 2018: 53), the researcher had conducted preliminary research to find information on interviews for several informants, namely 10 students to be sampled comprise : 5 people English Literature students from Al Ghifari University and
5 people Management students from STIE STEMBI Bandung.

Preliminary research will clarify the English airplane company slogans is an effective advertising objective to inform, persuade and remind consumers. Currently there are large companies in Indonesia do not use English slogans to advertise the company's products. In the preliminary study also conducted with literature study to sort out companies that can only use the English slogan. The number of companies in using to the English slogan can give good influence but the other side to improve the company performance, for example: Sriwijaya Air with English Slogan " Your Flying Partner".

Currently, the number of companies in doing marketing communication activities still use the advertising activities by creating English slogan. The role of English slogan here as a good advertising objective to inform, persuade and remind for customers to the company. In this study the researcher wants to analyze the English slogan changed based on semantic meaning on the phrase or sentence in the airplane slogan. Therefore the title of this study is "The Meaning in English Airplane Company Slogans : Semantic Studies".

\section{Identification of Problem}

Based on the description of the background of problem and the phenomenon of the research, the 
researcher can identify the problem as follows: (1) What is the meaning of each English slogan of international and domestic airplane companies in semantic study; (2) What is the purpose of each English slogan of international and domestic airplane companies in semantic study.

\section{Conceptual Frame Work}

In principle, the frame of thinking put forward some arguments, laws, theories relevant to the problems studied, so as to bring up the assumptions. The frame of thinking is a scheme or diagram that explains the flow of a study. Sugiyono (2018: 91) suggests that the frame of thinking explains the theoretical link between the variables to be studied. Based on the above explanation, the scheme can be created as shown in Picture 1.1 below.

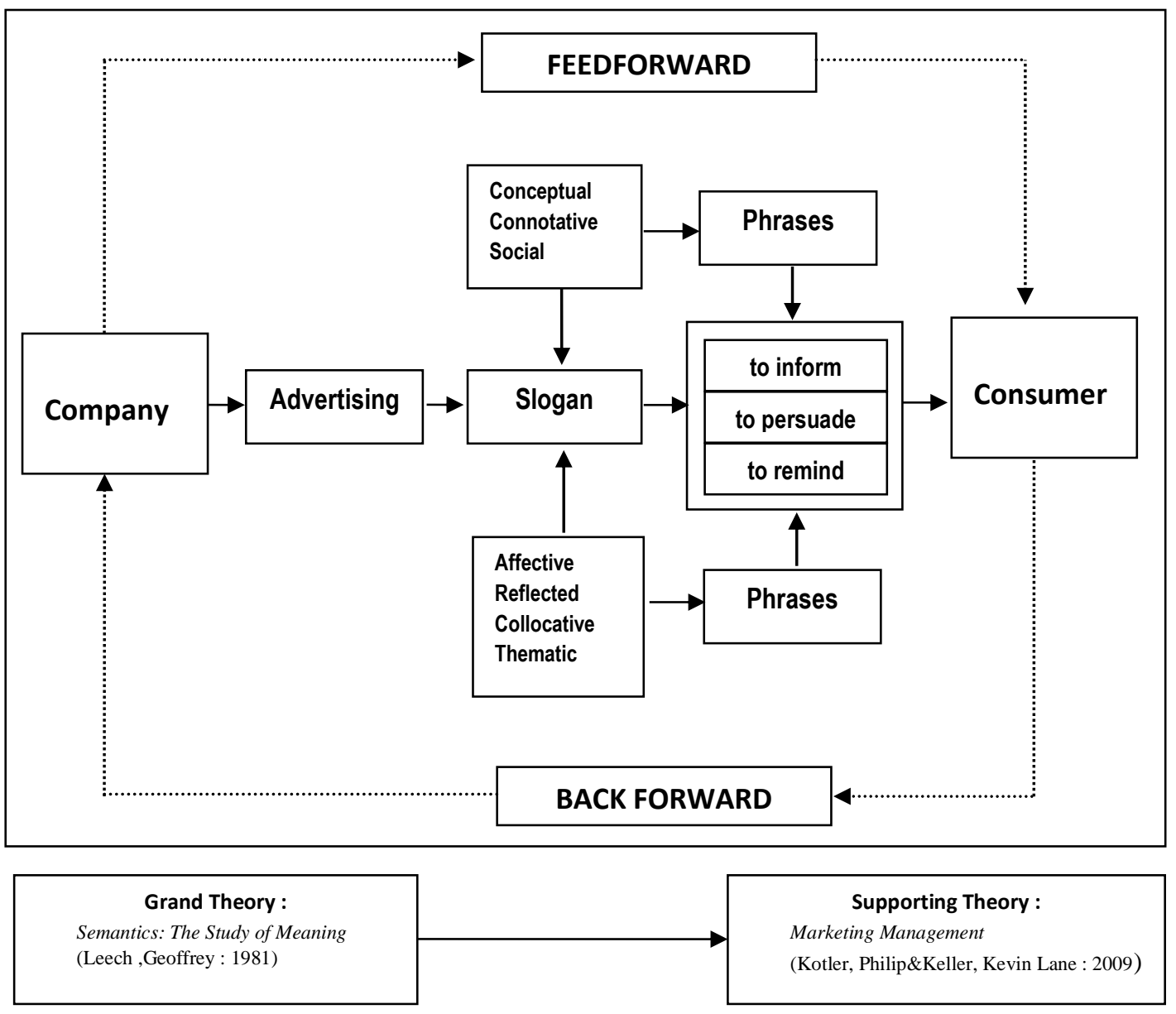

Picture 1.1 Frame of Thinking 


\section{LITERARY REVIEW}

\section{Semantics}

According to Oxford Advanced Learner's Dictionary (2010: 1342), semantics is "the study of the meanings of words and phrases". This is in line with what Kreidler (2002: 3) suggests about Semantic is the systematic study of meaning, and linguistic semantics is the study of how languages organize and express meanings. Further explanations are given by Griffiths (2006: 1) states that semantics is the study of the "toolkit" for meaning: knowledge encoded in the vocabulary of the language and in its patterns for building more elaborate meanings, up to the level of sentence meanings. Based on the number of definitions in general the researcher can convey that semantic understanding is the study of language and its meaning.

\section{Meaning}

Meanings are closely related to language and are an integral part of semantics. Meaning itself has a very wide and diverse understanding. Kriedler (2002: 46) states "meaning is more than denotation and connotation.
"While Aminnudin (2008: 16) argues there are some basic elements covered in the meaning is the result of the relationship between the language with the outside world, there is agreement with the user meaning, and the meaning that can be used to convey information so that there is a mutual communication understanding related to description above. It can be drawn the conclusion that the meaning is a relational association of words that is not just denotation and connotation only, but here is an agreement used in communicating very closely related to elements of the environment outside the language.

\section{Types of meaning}

Word has a big role in our lives, especially in communicating and most words have more than one meaning. Words are used to express something and also convey feelings about what we describe.

Some linguists have different views on the division of the seven types of meanings of the words, according to Leech (1981:23) that types of meaning as follows:

\section{Table 2.1 Seven Types of Meaning}

\begin{tabular}{|l|l|l|}
\hline \multicolumn{2}{|l|}{ CONCEPTUAL MEANING or Sense } & Logical, cognitive, or denotative content \\
\hline $\begin{array}{l}\text { ASSOCIATIVE } \\
\text { MEANING }\end{array}$ & $\begin{array}{l}\text { CONNOTATIVE } \\
\text { MEANING }\end{array}$ & $\begin{array}{l}\text { What is communicated by virtue of what } \\
\text { language refers to. }\end{array}$ \\
\hline
\end{tabular}




\begin{tabular}{|l|l|l|}
\hline & SOCIAL MEANING & $\begin{array}{l}\text { What is communicated of the social } \\
\text { circumstances of language use }\end{array}$ \\
\cline { 2 - 3 } $\begin{array}{l}\text { AFFECTIVE } \\
\text { MEANING }\end{array}$ & $\begin{array}{l}\text { What is communicated of the feelings } \\
\text { and attitudes of the speaker/writer. }\end{array}$ \\
\hline $\begin{array}{l}\text { REFLECTED } \\
\text { MEANING }\end{array}$ & $\begin{array}{l}\text { What is communicated through } \\
\text { association with another sense of the } \\
\text { same expression. }\end{array}$ \\
\hline $\begin{array}{l}\text { COLLOCATIVE } \\
\text { MEANING }\end{array}$ & $\begin{array}{l}\text { What is communicated through } \\
\text { association with words which tend to } \\
\text { occur in the environment of another } \\
\text { word. }\end{array}$ \\
\hline THEMATIC MEANING & $\begin{array}{l}\text { What is communicated by the way } \\
\text { which the message is organised in terms } \\
\text { of order and emphasis. }\end{array}$ \\
\hline
\end{tabular}

\section{Advertising}

Advertising is one form of communication from the company to consumers who are sent through certain media. Advertising deals with the creation of messages and sends them to others in this case are consumers in the hope of reacting in a certain way. If the consumer acts as the advertiser wants, then the ad is considered effective.

According to (Kotler \& Armstrong 1999: 450) the definition of advertising is "any paid form nonpersonal presentation and promotion of ideas, goods, or service by identified sponsors." Kotler here more emphasis on advertising in the marketing corner as a promotional tool that can help advertise the product or services that are produced or provided by the company.

\section{Advertising Objectives}

Companies often look for ways to increase their product or service consumption by repeating the image or the name of their product or service, in order to link the quality of the product in the consumer's memory. Advertising uses a variety of media to send communication messages to the minds of consumers in order to attract awareness and to embed information to consumers in the hope that there will be further action (purchase) after seeing or knowing the ad in accordance with advertising purposes.

According to (Kotler \& Armstrong 1999: 451) stated that the purpose of 
advertising is to to inform, persuade or remind. For more details can be seen in table 2.2

Table 2.2 Advertising Objectives

\begin{tabular}{|c|c|}
\hline TO INFORM & $\begin{array}{l}\text { - } \text { Telling the market about a new product } \\
\text { - } \quad \text { Suggesting new uses for a product } \\
\text { - } \quad \text { Informing the market of a price a change } \\
\text { - } \quad \text { Explaining how the product works } \\
\text { - } \quad \text { Describing available services } \\
\text { - } \quad \text { Correcting false impressions } \\
\text { - } \quad \text { Reducing buyers' fears }\end{array}$ \\
\hline TO PERSUADE & $\begin{array}{l}\text { - } \quad \text { Building brand preference } \\
\text { - } \quad \text { Encouraging switching to your brand } \\
\text { - } \quad \text { Changing customers perception of product atributes } \\
\text { - } \quad \text { Persuading customers to purchase now } \\
\text { - } \quad \text { Persuading customers to receive a sales call }\end{array}$ \\
\hline TO REMIND & $\begin{array}{l}\text { - Reminding customers that the product maybe needed in the } \\
\text { - } \text { near future } \\
\text { - } \text { Keminding customers where to buy the product } \\
\text { - Maintaining top-of-mind product awareness }\end{array}$ \\
\hline
\end{tabular}

\section{RESEARCH METHODOLOGY}

\section{Research Design}

This research aims to explore various English slogans from international and domestic airplane companies which low-cost and full service carriers using the Semantic approach. Therefore, the research method used by researcher is a qualitative research method. Qualitative research methods based on postpositivism or enterpretative paradigms are used to evaluate the condition of natural objects (not manipulated) where the position of the researcher itself is the main instrument (Sugiyono. 2018: 9)

Qualitative research instruments are data collection techniques carried out in triangulation (merging nonobservations, interviews and documentation), data obtained requires qualitative data, inductive / qualitative data analysis, and higher qualitative research results to gain meaning rather than generalization (Sugiyono, 2018: 10). Researcher used triangulation techniques to explore the truth of certain information through various stages and sources of data acquisition from collecting data, displayed, 
reducing and then determining the last data as needed.

\section{Sample of Data}

In this study the total population of 42 was chosen as the object of research or sample members. The population is still in detail again based on the type of service, namely as many as 29 Full Services airlines and 13 Low Cost Carrier airlines.

Furthermore, out of 42 total members, consisting of airlines operating in Indonesia, which have the following criteria: 1) international and domestic airlines, 2) English slogans, 3) AOC 121 provisions with a capacity of more than 30 seats, 4) scheduled commercial flights, 5) non cargo passenger flights and 6) international and domestic full service and low cost carrier airlines.

The list of 42 members of the sample airlines with English slogans are classified into 2 groups originating from International and domestic airlines which are Full Services and Low Cost Carriers.

\section{Research Instrument}

According to Sugiyono (2018: 101) In research that is an instrument or research that is a research in itself, which supports this researcher as a planner, executor of analysis and data collector as well as being a breaker of research results. Therefore researchers must have extensive insight into what will be announced.

Furthermore according to (Arikunto, 2013: 203) research instruments are tools or facilities used by researchers in collecting data so that their work is easier and produces better in the sense of being more careful, complete and systematic so that it is easier to process. Type of research instrument questionnaire, checklist (checklist) or checklist. Ceklis is a list of variables whose data will be collected. In this case the researcher only gives a sign or tally for every appearance of the proposed sign.

\section{Techniques of Collecting Data}

The data collection techniques used in this study are as follows:

\section{Literature review}

This literature review was conducted to obtain secondary data, namely by searching for and studying various theories that have to do with the problem being studied. In addition, researchers also collect and process data from journals and articles and through various internet sites.

\section{Interview}

The interview is a meeting of two people to exchange information and ideas through question and answer, so that meaning can be constructed in a particular topic (Sugiyono, 2018: 116).

The researcher uses semistructured interviews. The aim is to 
find problems and solutions more openly. Through semistructural interviews researchers also prepare a list of questions or interview guidelines so that data sources can answer questions according to a list of questions that the researchers have prepared in advance.

\section{Observation}

According to Nasution in Sugiyono (2018: 109) the data decided by the researchers will be able to discuss data, and a holistic view and not be revealed by interviews. With matters relating to observation, researchers can find things that will not be revealed by the respondent, things outside the perception of the respondent so that researchers can learn more and obtain personal images that are developing social situations of the objects discussed

\section{Triangulation}

Triangulation is defined as a technique of data collection that is related to various techniques for collecting data and existing data sources. If the researcher conducts data collection in triangulation, the researcher actually collects data which simultaneously tests the credibility of the data, namely checking the credibility of the data with various data collection techniques and various data sources.

According to Sugiyono (2018: 115) In the technique of collecting data, triangulation is interpreted as a Data Collection Technique that is a combination of various Data Techniques and existing data sources. If the researcher conducts data collection using triangulation, the researcher actually collects data which simultaneously tests the credibility of the data, namely checking the credibility of the data with Data Collection Techniques and various data sources.

Based on Leech data collection (1981), literature review, indepth interview , observation, and advertising model objective Table 2.3 by Kotler \& Armstong (1999), the characteristics of seven types of meanings are carried out to reduce and avoid ambiguous meanings as in table 3.4.

Table 3.1 The Characteristics of Seven Type Meanings

\begin{tabular}{|l|l|l|l|}
\hline No & Meanings & \multicolumn{1}{c|}{ Leech (1981) } & \multicolumn{1}{c|}{ Characteristics } \\
\hline 1 & $\begin{array}{l}\text { Conceptual } \\
\text { Meaning }\end{array}$ & $\begin{array}{l}\text { Logical, cognitive, } \\
\text { or denotative } \\
\text { content }\end{array}$ & $\begin{array}{l}\text { - It refers to the dictionary meaning which } \\
\text { indicates the concepts }\end{array}$ \\
& & $\begin{array}{l}\text { It is completely absent of emotion } \\
\text { It provides clear, literal definition. }\end{array}$ \\
\hline
\end{tabular}




\begin{tabular}{|c|c|c|c|}
\hline 2 & $\begin{array}{l}\text { Connotative } \\
\text { Meaning }\end{array}$ & $\begin{array}{l}\text { What is } \\
\text { communicated by } \\
\text { virtue of what } \\
\text { language refers to. }\end{array}$ & $\begin{array}{l}\text { - It refers to the associations that are } \\
\text { - connected to a certain word } \\
\text { - It refers to the associations the emotional } \\
\text { suggestions related to that word } \\
\text { - It is an additional meaning for a word or } \\
\text { phrase } \\
\text { - The connotative meanings of a word exist } \\
\text { together with the denotative meanings. }\end{array}$ \\
\hline 3 & $\begin{array}{l}\text { Social } \\
\text { Meaning }\end{array}$ & $\begin{array}{l}\text { What is } \\
\text { communicated of } \\
\text { the social } \\
\text { circumstances of } \\
\text { language use. }\end{array}$ & $\begin{array}{l}\text { - It refers to the usage of language in and by } \\
\text { society which has big proportions in } \\
\text { determining the meaning that certain } \\
\text { speaker has to use and wants to convey } \\
\text { - those factors include social class of the } \\
\text { speaker and hearer and the degree of } \\
\text { formality } \\
\text { - Only part of the social meaning of a } \\
\text { conversation is carried by words. } \\
\text { - Social meaning relates to the use of } \\
\text { language to establish and regulate social } \\
\text { relations and to maintain social roles. }\end{array}$ \\
\hline 4 & $\begin{array}{l}\text { Affective } \\
\text { Meaning }\end{array}$ & $\begin{array}{l}\text { What is } \\
\text { communicated of } \\
\text { the feelings and } \\
\text { attitudes of the } \\
\text { speaker/writer }\end{array}$ & $\begin{array}{l}\text { - It refers to the speaker's feeling / attitude } \\
\text { towards the content or the ongoing } \\
\text { context. } \\
\text { - The tone of voice is really important to } \\
\text { show the emotion since the listener will } \\
\text { understand the feeling of the speaker if he } \\
\text { is sad, angry, bad, or happy through the } \\
\text { intonation of the speaker } \\
\text { - It is important to remember that each } \\
\text { individual will have a different affective } \\
\text { meaning for a word. }\end{array}$ \\
\hline 5 & $\begin{array}{l}\text { Reflective } \\
\text { Meaning }\end{array}$ & $\begin{array}{l}\text { What is } \\
\text { communicated } \\
\text { through association } \\
\text { with another sense } \\
\text { of the same } \\
\text { expression }\end{array}$ & $\begin{array}{l}\text { - It refers to terms which have more than } \\
\text { one meaning surfaces at the same time, so } \\
\text { there is a kind of ambiguity. } \\
\text { - The meaning which arises in case of } \\
\text { multiple conceptual meaning when the } \\
\text { sense of word parts of our response to } \\
\text { another sense. } \\
\text { - it is possible to make either secondary or } \\
\text { substitution meaning for the same words } \\
\text { which are reflected to familiar reference of } \\
\text { the word in society. } \\
\text { This meaning mostly refers to the taboo, } \\
\text { sacred condition, and attitude. }\end{array}$ \\
\hline 6 & $\begin{array}{l}\text { Collocative } \\
\text { Meaning }\end{array}$ & $\begin{array}{l}\text { What is } \\
\text { communicated } \\
\text { through association } \\
\text { with words } \\
\text { whichtend to occur }\end{array}$ & $\begin{array}{l}\text { - It refers to the associations a word } \\
\text { acquires on account of the meanings of } \\
\text { words which tend to occur in its } \\
\text { environment. }\end{array}$ \\
\hline
\end{tabular}




\begin{tabular}{|c|c|c|c|}
\hline & & $\begin{array}{l}\text { in the environment } \\
\text { of another word. }\end{array}$ & $\begin{array}{l}\text { - it is that part of the word-meaning } \\
\text { suggested by the words that go before or } \\
\text { come after a word in question. } \\
\text { - This meaning is concerned with certain } \\
\text { meaning traits that have a word from a } \\
\text { number of synonymous words. } \\
\text { - The word is only suitable for use in pairs } \\
\text { with certain other words }\end{array}$ \\
\hline 7 & $\begin{array}{l}\text { Thematic } \\
\text { Meaning }\end{array}$ & $\begin{array}{l}\text { What is } \\
\text { communicated by } \\
\text { the way which the } \\
\text { message is } \\
\text { organised in terms } \\
\text { of order and } \\
\text { emphasis. }\end{array}$ & $\begin{array}{l}\text { - It relates to or constitutes a topic of } \\
\text { discourse } \\
\text { - The meaning that the word conveys is that } \\
\text { of something that is connected with the } \\
\text { theme of something } \\
\text { - The meaning of the theme is } \\
\text { communicated in a way in which a } \\
\text { speaker or writer arranges the message, in } \\
\text { terms of ordering, focus, and emphasis. }\end{array}$ \\
\hline
\end{tabular}

\section{DATA ANALYSIS DISCUSSION}

AND

The first step is the English slogans of the airplanes by researcher to find meaning by using the semantic study approach namely Seven Type Meaning according to Leech (1981: 23) consisting of: conceptual meaning, connotative meaning, social meaning, affective meaning, reflected meaning, and collocative meaning.

In this discussion the researchers are guided by Conceptual Frame Work, as shown in Figure 1.1 Frame of Thinking, which is the entire research process including input - process output linking research problems, conducting research conducted alternately between data collection and data analysis until finally the whole research problem can answered.

Data : Air Asia (1), Slogan : Now Everyone Can Fly, Analysis : A word
Fly according to Cambridge Advanced Learner's Dictionary 4th Edition is to travel by aircraft, or to go somewhere or cross something in an aircraft. A word Now has meaning is under the present circumstances; as a result of something that has recently happened. Everyone Can Fly can be considered that flying is possible and achievable by everyone around any corner of the world. Based on data company in website Air Asia, the meaning of Now Everyone Can Fly is traveling by aircraft is possible and achievable by everyone around any corner of the world under the present circumstances of low cost carrier. Based on the meaning, the most suitable meaning of the slogan is Conceptual Meaning because it refers to the dictionary meaning which indicates the concepts and it provides clear, literal definition.

$$
\text { Data : Xiamen Airlines (42), }
$$
Slogan : New horizons with Xiamen Air 
Analysis: According to Oxford Advanced Learner's Dictionary International Student's Edition, Horizon is the furthest that you can see, where the sky seems to meet the land or the sea. Horizon also has meaning the limit of your desires, knowledge or interests.Related to the company slogan on the website,New horizons with Xiamen Air in the text slogan has meaning the airline tried to expand its presence in the world with new route. Based on the meaning, the most suitable meaning of the slogan is Connotative Meaning because it refers to the associations that are connected to a certain word, it is an additional meaning for a word or phrase, and The connotative meanings of a word Horizon exist together with the denotative meanings.

Table 4.1 Data Findings : The Seven Type of Meaning in each English International and Domestic Airplane Company Slogans

\begin{tabular}{|c|c|c|c|c|c|c|c|c|c|}
\hline Eng & Airplane Company & Type of Meaning & $\begin{array}{c}\text { TM } \\
1\end{array}$ & $\begin{array}{c}\text { TM } \\
2\end{array}$ & $\begin{array}{c}\text { TM } \\
3\end{array}$ & $\begin{array}{c}\mathrm{TM} \\
4\end{array}$ & $\begin{array}{c}\mathrm{TM} \\
5\end{array}$ & $\begin{array}{c}\text { TM } \\
6\end{array}$ & $\begin{array}{c}\mathrm{TM} \\
7\end{array}$ \\
\hline 1 & Air Asia & Now Everyone Can Fly & $\checkmark$ & & & & & & \\
\hline 2 & Airfast Indonesia & We'll Fly You Safely & & & & & & & $\sqrt{ }$ \\
\hline 3 & Air China & Land Your Dream & & & & & & & $\checkmark$ \\
\hline 4 & All Nippon Airways & Inspiration of Japan & & & & $\checkmark$ & & & \\
\hline 5 & Asiana Airlines & Beautiful people & & & & $\sqrt{ }$ & & & \\
\hline 6 & Batik Air & Journey Begins & & & & & & & $\sqrt{ }$ \\
\hline 7 & Cathay Pacific & Fly with Us and Travel Well & & & & & & & $\checkmark$ \\
\hline 8 & Cebu Pacific & Let's Take to the Sky & & & & & & & $\checkmark$ \\
\hline 9 & China Airlines & Journey with a caring smile & & & & $\sqrt{ }$ & & & \\
\hline 10 & $\begin{array}{l}\text { China Eastern } \\
\text { Airlines }\end{array}$ & $\begin{array}{l}\text { World-Class Hospitality with Eastern } \\
\text { Charm }\end{array}$ & & & & $\sqrt{ }$ & & & \\
\hline 11 & $\begin{array}{l}\text { China Southern } \\
\text { Airlines }\end{array}$ & Fly into your dreams & & & & & & & $\checkmark$ \\
\hline 12 & Citilink & Better fly, Citilink & & & & & & & $\checkmark$ \\
\hline 13 & Emirates & Fly Emirates. Keep Discovering & & & & & & & $\checkmark$ \\
\hline 14 & Ethiopian Airlines & The New Spirit of Africa & & & & & $\sqrt{ }$ & & \\
\hline 15 & Etihad Airways & From Abu Dhabi to the world & $\checkmark$ & & & & & & \\
\hline 16 & EVA Air & Just Relax, Your Home in The Air & & & & $\sqrt{ }$ & & & \\
\hline 17 & Flynas & The Kingdom's First Low-Cost Airline & $\sqrt{ }$ & & & & & & \\
\hline 18 & Garuda Indonesia & The Airline of Indonesia & $\checkmark$ & & & & & & \\
\hline 19 & Japan Airlines & Fly for it & & & & & & & $\checkmark$ \\
\hline 20 & Jetstar Airways & Australia's No. 1 Low Fares Airline & $\sqrt{ }$ & & & & & & \\
\hline 21 & KLM & Journeys of Inspiration & & & & $\sqrt{ }$ & & & \\
\hline 22 & Korean Air & Excellence in Flight & & & & $\sqrt{ }$ & & & \\
\hline 23 & Lion Air & We make people fly & $\sqrt{ }$ & & & & & & \\
\hline
\end{tabular}




\begin{tabular}{|c|c|c|c|c|c|c|c|c|}
\hline 24 & Malaysia Airlines & More than just an airline code & & & & & & \\
\hline 25 & Malindo Air & Not Just Low Cost & & & & & & $\checkmark$ \\
\hline 26 & Nam Air & Your flying Partner & & & & & & $\sqrt{ }$ \\
\hline 27 & Oman Airlines & Modern Vision. Timeless Traditions & & & & $\checkmark$ & & \\
\hline 28 & Philippine Airlines & The Heart of the Filipino & & & & & $\checkmark$ & \\
\hline 29 & Qantas Air & The Spirit of Australia & & & & $\checkmark$ & & \\
\hline 30 & Qatar Airways & Going Places Together & & $\checkmark$ & & & & \\
\hline 31 & $\begin{array}{l}\text { Royal Brunai } \\
\text { Airlines }\end{array}$ & Giving the world Asia's best & $\checkmark$ & & & & & \\
\hline 32 & Scoot & Get Outta Here! & & & $\sqrt{ }$ & & & \\
\hline 33 & SilkAir & Where the world unwinds & & $\sqrt{ }$ & & & & \\
\hline 34 & Singapore Airlines & A Great Way to Fly & & & & & & $\checkmark$ \\
\hline 35 & Sri Lankan Airlines & Ready to Fly & & & & & & $\sqrt{ }$ \\
\hline 36 & Sriwijaya Air & Your Flying Partner & & & & & & $\checkmark$ \\
\hline 37 & Thai Airways & Smooth as silk & & $\sqrt{ }$ & & & & \\
\hline 38 & Tiger Air & Go for it & & & & & & $\checkmark$ \\
\hline 39 & Turkish Airlines & Widen Your World & & & & & & $\sqrt{ }$ \\
\hline 40 & Virgin Australia & Now You're Flying & & & & & & $\sqrt{ }$ \\
\hline 41 & Wing Air & Flying is cheap & $\checkmark$ & & & & & \\
\hline 42 & Xiamen Airlines & New horizons with Xiamen Air & & $\checkmark$ & & & & \\
\hline
\end{tabular}

: Conceptual Meaning $=8$

: Social Meaning = 1

: Reflected Meaning $=3$

: Thematic Meaning $=18$
TM2 : Connotative Meaning $=4$

TM4 : Affective Meaning = 8

TM6 : Collocative Meaning $=0$
Data : Air Asia (1), Slogan : Now Everyone Can Fly, Analysis : Now Everyone Can Fly in the text slogan telling about the fact that everyone can easily travel by plane now. This is due to low-cost carrier. Based on data company website, AirAsia became a pioneer in the aviation industry, and became the first to pioneer the

Table 4.2 The Purpose of Each English International and Domestic Airplane Company Slogans in connection with Advertising Objective to customers

\begin{tabular}{|l|l|l|c|c|c|}
\hline \multicolumn{2}{|c|}{ Advertising Objectives } & $\begin{array}{c}\text { To } \\
\text { Inform }\end{array}$ & $\begin{array}{c}\text { To } \\
\text { Persuade }\end{array}$ & $\begin{array}{c}\text { To } \\
\text { Remind }\end{array}$ \\
\hline 1 & Air Asia & Now Everyone Can Fly & $\checkmark$ & & \\
\hline 2 & Airfast Indonesia & We'll Fly You Safely & & $\checkmark$ & \\
\hline 3 & Air China & Land Your Dream & & $\checkmark$ & \\
\hline 4 & All Nippon Airways & Inspiration of Japan & & & \\
\hline 5 & Asiana Airlines & Beautiful people & $\checkmark$ & & \\
\hline
\end{tabular}

development of the low-cost travel market in the Asia Pacific. Based on advertising objective is to inform because the informative about Air Asia became pioneer the development of the low-costcarrier is used to introduce a brand new company product to the marketing. 


\begin{tabular}{|c|c|c|c|c|c|}
\hline 6 & Batik Air & Journey Begins & $\sqrt{ }$ & & \\
\hline 7 & Cathay Pacific & Fly with Us and Travel Well & & $\sqrt{ }$ & \\
\hline 8 & Cebu Pacific & Let's Take to the Sky & & $\sqrt{ }$ & \\
\hline 9 & China Airlines & Journey with a caring smile & $\sqrt{ }$ & & \\
\hline 10 & China Eastern Airlines & $\begin{array}{l}\text { World-Class Hospitality with Eastern } \\
\text { Charm }\end{array}$ & $\checkmark$ & & \\
\hline 11 & China Southern Airlines & Fly into your dreams & & $\sqrt{ }$ & \\
\hline 12 & Citilink & Better fly, Citilink & & $\sqrt{ }$ & \\
\hline 13 & Emirates & Fly Emirates. Keep Discovering & & $\checkmark$ & \\
\hline 14 & Ethiopian Airlines & The New Spirit of Africa & $\sqrt{ }$ & & \\
\hline 15 & Etihad Airways & From Abu Dhabi to the world & $\sqrt{ }$ & & \\
\hline 16 & EVA Air & Just Relax, Your Home in The Air & & & $\sqrt{ }$ \\
\hline 17 & Flynas & The Kingdom's First Low-Cost Airline & $\checkmark$ & & \\
\hline 18 & Garuda Indonesia & The Airline of Indonesia & $\sqrt{ }$ & & \\
\hline 19 & Japan Airlines & Fly for it & & $\sqrt{ }$ & \\
\hline 20 & Jetstar Airways & Australia's No. 1 Low Fares Airline & $\sqrt{ }$ & & \\
\hline 21 & KLM & Journeys of Inspiration & & & $\checkmark$ \\
\hline 22 & Korean Air & Excellence in Flight & & & $\checkmark$ \\
\hline 23 & Lion Air & We make people fly & $\checkmark$ & & \\
\hline 24 & Malaysia Airlines & More than just an airline code & & & $\sqrt{ }$ \\
\hline 25 & Malindo Air & Not Just Low Cost & $\checkmark$ & & \\
\hline 26 & Nam Air & Your flying Partner & $\sqrt{ }$ & & \\
\hline 27 & Oman Airlines & Modern Vision. Timeless Traditions & $\checkmark$ & & \\
\hline 28 & Philippine Airlines & The Heart of the Filipino & $\sqrt{ }$ & & \\
\hline 29 & Qantas Air & The Spirit of Australia & $\checkmark$ & & \\
\hline 30 & Qatar Airways & Going Places Together & & $\checkmark$ & \\
\hline 31 & Royal Brunai Airlines & Giving the world Asia's best & $\sqrt{ }$ & & \\
\hline 32 & Scoot & Get Outta Here! & $\sqrt{ }$ & & \\
\hline 33 & SilkAir & Where the world unwinds & $\sqrt{ }$ & & \\
\hline 34 & Singapore Airlines & A Great Way to Fly & & $\sqrt{ }$ & \\
\hline 35 & Sri Lankan Airlines & Ready to Fly & & $\sqrt{ }$ & \\
\hline 36 & Sriwijaya Air & Your Flying Partner & $\sqrt{ }$ & & \\
\hline 37 & Thai Airways & Smooth as silk & $\sqrt{ }$ & & \\
\hline 38 & Tiger Air & Go for it & & $\sqrt{ }$ & \\
\hline 39 & Turkish Airlines & Widen Your World & & $\checkmark$ & \\
\hline 40 & Virgin Australia & Now You're Flying & $\sqrt{ }$ & & \\
\hline 41 & Wing Air & Flying is cheap & $\checkmark$ & & \\
\hline 42 & Xiamen Airlines & New horizons with Xiamen Air & $\checkmark$ & & \\
\hline
\end{tabular}

To Inform : $25 \quad$ To Persuade: 13

To Remind : 4

In conducting the next analysis the researchers grouped 42 units of analysis for the Airline Low Cost Carrier group into 3 sub groups namely: 1) International Low Cost Carrier VS International Low Cost
Carrier, 2) International Low Cost Carrier VS Domestic Low Cost Carrier, 3) Domestic Low Cost Carrier VS Domestic Low Cost Carrier, As for the Full Service Carrier group, there are 3 sub groups: 1) International Full Service 
Carrier VS International Full Service

Carrier, 2) International Full Service

Carrier VS Domestic Full Service

Carrier, 3) Domestic Full Service

Carrier VS Domestic Full Service

Carrier.
Researcher in conducting an analysis of the International Low Cost Carrier with Airline Different Test Analysis Standards using Airline Key Performance Indicators (KPI) which includes: Safety, Flight Operation and Finance, the following results :

Table 4.3 International Low-cost Carrier vs International Low-cost Carrier (2018)

\begin{tabular}{|c|l|l|l|}
\hline No & Difference Test & \multicolumn{1}{c|}{ Cebu Pasific } & Air Asia X \\
\hline 1 & Safety & $\begin{array}{l}\text { On 23 April 2018, the crew needed to } \\
\text { stop the aircraft due to a nose gear } \\
\text { steering fault. no passengers or crew } \\
\text { were injured }\end{array}$ & Zero accident \\
\hline 2 & Flight Operation & 53 & Revenue : US\$ 1.12 billion \\
\hline 3 & Finance & Finance Performance : Profit & Finance Performance : Loss \\
\hline
\end{tabular}

(processed from various sources)

Although with a smaller number of airline and finance performance loss, Air Asia X had a zero accident in 2018 which places it better than cebu pacific.

Table 4.4 International Low-cost Carrier vs Domestic Low-cost Carrier (2018)

\begin{tabular}{|c|c|c|c|}
\hline No & Difference Test & $\begin{array}{c}\text { Jet Star Airways } \\
\text { Australia's No. } 1 \text { Low Fares Airline }\end{array}$ & $\begin{array}{c}\text { Lion Air } \\
\text { We Make People Fly }\end{array}$ \\
\hline 1 & Safety & Zero Accident & $\begin{array}{l}\text { On } 29 \text { October 2018, Lion Air } \\
\text { Flight } 610 \text {, a Boeing } 737 \text { MAX 8, } \\
\text { crashed in the Java Sea } 12 \\
\text { minutes after takeoff from } \\
\text { Jakarta, killing all } 189 \text { people on } \\
\text { board }\end{array}$ \\
\hline 2 & Flight Operation & 71 & 117 \\
\hline 3 & Finance & $\begin{array}{l}\text { Revenue : } \mathrm{A} \$ 3.636 \text { billion } \\
\text { Finance Performance : Profit }\end{array}$ & $\begin{array}{l}\text { Revenue : IDR } 36 \text { T (est) } \\
\text { Finance Performace: Loss }\end{array}$ \\
\hline
\end{tabular}

(processed from various sources) 
Jetstar is better than Lion air with zero accident meanwhile a Boeing 737 MAX 8, Lion Air crashed in the Java Sea 12 minutes after take off from Jakarta, killing all 189 people on board.
Jetstar is one of the world's top 10 safest low-cost airlines. Jetstar Airways financial performance is profit while Lion Air financial performance is loss.

Table 4.5 Domestic Low-cost Carrier vs Domestic Low-cost Carrier (2018)

\begin{tabular}{|c|l|l|l|}
\hline No & \multicolumn{1}{|c|}{ Difference Test } & \multicolumn{1}{c|}{$\begin{array}{c}\text { Citilink } \\
\text { Better fly, Citilink }\end{array}$} & \multicolumn{1}{c|}{$\begin{array}{c}\text { Wing Air } \\
\text { Flying is Cheap }\end{array}$} \\
\hline 1 & Safety & Zero accident & Zero accident \\
\hline 2 & Flight Operation & 57 & Revenue : IDR 36 T (est) \\
& Finance & Finance Performance: Loss & Finance Performance: Loss \\
\hline
\end{tabular}

(processed from various sources)

The advantage of Citilink is segmentation and consumer shots that have been firmly stated from the start. With a holding company working on premium business, Citilink has a clear segment that is targeting the lower classes. Garuda's support can also be an advantage for Citilink. Wing Air and its parent airline still have to fix a number of problems that are often complained by consumers. This Rusdi Kiranaowned company is expected to be able to improve its quality of service and safety standards. As per the company's Slogans, Citilink and Wing Air both inform the Airline Low Cost Carrier publicly, but in reality they are Full Service Carriers. The management of the two Airlines is inconsistent in doing business.

Table 4.6 International Full Service Carrier vs International International Full Service (2018)

\begin{tabular}{|c|l|l|l|}
\hline No & \multicolumn{1}{|c|}{ Difference Test } & \multicolumn{1}{c|}{$\begin{array}{c}\text { Singapore Airline } \\
\text { A Great Way to Fly }\end{array}$} & \multicolumn{1}{c|}{ Keep discovering } \\
\hline 1 & Safety & Zero accident & Zero accident \\
\hline 2 & Flight Operation & 127 & Revenue : US\$ 13.3 billion \\
\hline 3 & Finance & Revenue : S\$11.6 billion & Finance Performance: Loss \\
\hline
\end{tabular}


Emirates and Singapore Airlines are known for their high standards of service, with both airlines being ranked high among the top airlines in the world every year. One can be better

Table 4.7 International Full Service Carrier vs Domestic Full Service Carrier (2018)

\begin{tabular}{|c|l|l|l|}
\hline No & \multicolumn{1}{|c|}{ Difference Test } & \multicolumn{1}{c|}{$\begin{array}{c}\text { China Airlines } \\
\text { Journey with a caring smile }\end{array}$} & \multicolumn{1}{c|}{$\begin{array}{c}\text { Sriwijaya Air } \\
\text { Your Flying Partner }\end{array}$} \\
\hline 1 & Safety & Zero Accident & Zero Accident \\
\hline 2 & Flight Operation & 88 & 12 \\
\hline 3 & Finance & NTD139.815 billion & IDR 1,2 T (est) \\
& & Finance Performance: Profit & Finance Performance: Loss \\
\hline
\end{tabular}

(processed from various sources)

China Airline is the national carrier of Taiwan so in all aspects it exceeds Sriwijaya Air specifically in the field of than other that is all and things are dynamic. In the field of finance, Singapore Airline is better because its financial position is profitable.

Table 4.8 Domestic Full Service Carrier vs Domestic Full Service Carrier (2018)

\begin{tabular}{|c|l|l|l|}
\hline No & \multicolumn{1}{|c|}{ Difference Test } & \multicolumn{1}{|c|}{$\begin{array}{c}\text { Garuda Indonesia } \\
\text { The Airline of Indonesia }\end{array}$} & \multicolumn{1}{c|}{ Batik Air } \\
\hline 1 & Safety & Zero Accident & Zero Accident \\
\hline 2 & Flight Operation & 139 & 54 \\
\hline 3 & Finance & $\begin{array}{l}\text { Revenue : US\$3.86 billion (Rp53.08 } \\
\text { trillion) } \\
\text { Finance Performance: Loss }\end{array}$ & Revenue : 36 T (est) \\
\hline
\end{tabular}

(processed from various sources)

Garuda Indonesia Passengers most business people and tourists are looking for excellent services while Air Batik passengers are "upgraded" passengers from low-cost airlines, looking for slightly better services. Garuda Indonesia is better than Batik
Finance, China Airlines Finance performance profit position while Sriwijaya Airlines loss. 
company's goal is to make the Advertising Slogan not fulfilled and preferably if there is no change in company policy rates, we recommend that the Advertising Slogan content be changed because it is not in line with the company's business behavior and is counterproductive.

\section{CONCLUSION SUGESSTIONS}

AND

Based on the results of the research and field findings to be able to answer the identification of problems in chapter 1, In conducting semantics analysis the researcher used the seven types of meaning theory Leech (1981) to analyze each advertising English slogan from 42 airlines as an object of research. To maintain consistency in analyzing the researchers first need to arrange the characteristics of the seven types of meaning. The next step of 42 advertising English slogans researchers grouped into seven types of meaning, namely: Conceptual meaning, Connotative meaning, Social meaning, Affective meaning, Reflected meaning, Collocative meaning and Thematic meaning.

The final results of analyzing the activities of 42 English slogans of airplane company slogans operating in Indonesia were found using Thematic meaning. It means airplane company are service companies engaged in the field of air transportation, the main theme that is usually carried is usually always related to safety, so it's not surprising that there are many words of "safety" that are the focus and emphasis in their slogans. Some other airplane company try to say in their slogan that the company is better, more friendly, warmer in terms of comfort in traveling using their airplane company.

In conducting an analysis of 42 advertising airplane company slogans associated with the purpose of advertising to customers, the researcher used namely: to inform, to persuade and to remind.The final result of the analysis of 42 English slogans of airplane company operating in Indonesia that the researchers found that the company's goal of advertising slogans was to inform customers. Only when it comes to implementation on the ground requires consistency between the slogans being communicated to the public and company policies.

Furthermore, by conducting different tests on airline slogans grouping based on the type of service, namely: Full Service Carrier Airline and Low Cost Carrier Airline using Key Performance Indicators (KPI) Airline includes the elements: Safety, Flight Operations and Finance shows that it contains meaning the low cost carrier flight model is developing rapidly in the world. Through unique service offerings, almost anyone can fly comfortably to various destinations, 
without having to pay high fees. The results show that domestic low cost carrier companies such as: Citilink Airline, Lion Airline, Wing Air with low cost carrier slogans are in fact Full Service Carriers with normal fees.

In contrast to other International and Domestic Low Cost Carrier groups such as: Air Asia, Jetstar, Malindo Air, Cebu Pacific, Silk Air and others are consistent according to their slogan as low cost carriers. 


\section{Bibliography}

Aminuddin. 2008. Semantik (Pengantar Studi tentang Makna). Bandung: Sinar Baru Algensindi

Arikunto, Suharsimi. 2013. Prosedur Penelitian : Suatu Pendekatan Praktik. Edisi Revisi VI. Jakarta : PT Rineka Cipta.

Bussmann, H. (1996). Routledge Dictionary of Language and Linguistics. London: Routledge.

Cambridge Advance Learner's Dictionary 4th Edition. 2013. Cambridge University Press

Chaer, Abdul. 1990. Pengantar semantik bahasa Indonesia. Rineka Cipta

Cook, Guy. 1998. Applied Linguistic. Oxford

Crystal, David, 2003. English as Global Language. 2nd Edition. Cambridge University Press

Dalrymple, Douglas J., Parsons, Leonard J. 1980. Marketing Management: Text and Cases. USA:John Wiley

Dan Taylor. 2018. How to Write an Effective Slogan. https://businesstown.com/howto-write-an-effective-slogan/ Accessed On November 22, 2018

Dewa Putu dan Muhammad Rohmadi. 2008. Semantik: teori dan analisis. Surakarta: Yuma Pustaka

Djajasudarma, Fatimah. 2013. Semantik I "Pengantar ke arah ilmu makna". Bandung: PT Eresco Bandung

Fromkin, V·, Robert R·, Nina H· (2003). An Introduction to Language (7th ed·) Australia: Thomson Wadsworth

Ginting, Enda Christiani Nora.2017. Semantic Analysis of Fast Food Advertisement Slogans.Faculty of Cultural Sciences University of Sumatera Utara

Graddol, D. 2006. The Future of English. London: British Council

Griffiths, Patrick. 2006. An Introduction to English Semantics and Pragmatics. Edinburgh University Press Lt

Hilmil Irfan, Asep. 2017. The Analysis of Associative Meaning in Samsung Advertisement Slogan. Thesis. English Department faculty of Adab and Cultural Science State Islamic University Sunan Kalijaga Yogyakarta

https://w3techs.com/technologies/overview/content_language accesed on November 18, 2018

https://www.statista.com, accessed on November 18, 2018

Huda, Nailul, 2019. “Empat Kesalahan Pengelolaan Industri Penerbangan". Jakarta: Kompas, Rabu 10 Juli.

Ibrahim, Murtala. 2015. Semantic Analysis of Language Advertisement in Daily Trust and Vanguard Newspaper. The Department of Modern European Language and Linguistics, Faculty of Arts and Islamic Studies, Usumanu Danfodiyo University, Sakoto

Kotler \& Amstrong.1999. Principles of Marketing. Prentice-Hall International Inc Kotler, Philip. 2009. Manajemen Pemasaran. Edisi 13. Jakarta: Erlangga

Kreidler, Charles. 2002. Introducing English Semantics. Routledge Publisher Leech ,Geoffrey. 1981. Semantics: The Study of Meaning. Penguin Publisher. 